\title{
Desenvolvimento do sistema sensório motor oral e motor global em lactentes pré-termo $* * * * *$
}

\author{
Sensory oral motor and global motor development of preterm infants
}

\begin{abstract}
Adriana Guerra de Castro* Marilia de Carvalho Lima** Rebeca Raposo de Aquino*** Sophie Helena Eickmann $* * * *$
\end{abstract}

*Fonoaudióloga. Mestre em Saúde da Criança e do Adolescente pela Universidade Federal de Pernambuco. Professora do Curso de

Fonoaudiologia da Fundação de Ensino Superior de Olinda. Endereço para correspondência: Rua Conselheiro Portela, 130B Apto. 1402 - Recife - PE - CEP 52020-030 (afono@uol.com.br).

**Doutora em Medicina pela London School of Hygiene and Tropical Medicine - Universidade de Londres. Professora Adjunta do Departamento Materno Infantil da Universidade Federal de Pernambuco.

***Fonoaudióloga. Mestre em Saúde da Criança e do Adolescente pela Universidade Federal de Pernambuco. Fonoaudióloga do Instituto Materno Infantil Professor Fernando Figueira.

*****Doutora em Nutrição em Saúde Pública pela Universidade Federal de Pernambuco. Professora Adjunta do Departamento Materno Infantil da Universidade Federal de Pernambuco.

*****Pesquisa Realizada na PósGraduação em Saúde da Criança e do Adolescente na Universidade Federal de Pernambuco.

Artigo de Pesquisa

Artigo Submetido a Avaliação por Pares Conflito de Interesse: não

Recebido em 30.03.2006. Revisado em 03.06.2006; 05.09.2006; 15.03.2007.

Aceito para Publicação em 15.03.2007.

\section{Abstract}

Background: development assessment of preterm infants. Aim: to evaluate the association between the gestational ages (GA) of premature infants with the global motor development as well as with early signs of sensory oral motor development delay, and to verify a possible association between them. Method: an exploratory study that assessed the development of 55 infants with corrected chronological ages between four to five months, born preterm at the Instituto Materno Infantil Professor Fernando Figueira (IMIP) and who were followed at the Kangaroo Mother Program Clinic between March and August of 2004. The assessment of the sensory oral motor development was performed through preselected indicators and of the global motor development through the Alberta Infant Motor Scale (AIMS). Results: infants with lower GA (29 to 34 weeks) presented a higher median of risk signs in the sensory oral motor development assessment when compared to those with higher GA (35 to 36 weeks). Regarding the global motor development, infants born with lower GA presented a higher number of scores in the AIMS below percentile 10 (26\%) when compared to those with a higher GA (4\%) $(\mathrm{p}=0.009)$. The median index of the risk signs for the sensory oral motor development were significantly higher among infants with total AIMS scores below percentile 25 when compared to those with scores equal to or above percentile 25. Conclusion: the gestational age of infants at birth influenced the sensory oral motor and global motor development - infants with lower gestational ages presented worse performances. These findings suggest a possible association between both aspects of infant development.

Key Words: Infant Premature; Child Development; Psychomotor Performance; Stomatognathic System.

\section{Resumo}

Tema: avaliação do desenvolvimento de lactentes nascidos pré-termo. Objetivo: avaliar associação entre a idade gestacional (IG) de lactentes nascidos pré-termo com o desenvolvimento motor global e com sinais precoces de alteração do desenvolvimento do sistema sensório motor oral, verificando uma possível associação entre eles. Método: estudo exploratório que avaliou o desenvolvimento de 55 lactentes com idade cronológica corrigida entre quatro e cinco meses, nascidos pré-termo no Instituto Materno Infantil Professor Fernando Figueira (IMIP) e acompanhados no Ambulatório de Egressos do Programa Mãe Canguru, no período de março a agosto de 2004. A avaliação do desenvolvimento do sistema sensório motor oral foi realizada através de indicadores pré-selecionados e a do desenvolvimento motor global através da Alberta Infant Motor Scale (AIMS). Resultados: os lactentes com menor IG ao nascer (29 a 34 semanas) apresentaram uma mediana mais elevada do índice de sinais de risco na avaliação do desenvolvimento sensório motor oral, quando comparados com os nascidos com maior IG (35 a 36 semanas). Em relação ao desenvolvimento motor, os lactentes com menor IG ao nascer apresentaram um maior percentual de escore da AIMS abaixo do percentil 10 (26\%), quando comparado com os nascidos com maior IG $(4 \%)(\mathrm{p}=0,009)$. A mediana do índice dos sinais de risco para o desenvolvimento sensório motor oral foi significantemente maior entre os lactentes com escore total da AIMS inferior ao percentil 25, quando comparada com os que apresentaram escore igual ou maior que o percentil 25. Conclusão: a idade gestacional dos lactentes ao nascer influenciou o desenvolvimento do sistema sensório motor oral e motor global em detrimento dos RN com menor IG. Esses achados sugerem uma possível associação entre ambos aspectos do desenvolvimento infantil.

Palavras-Chave: Recém-Nascido; Prematuro; Desenvolvimento Infantil; Desempenho Psicomotor; Sistema Estomatognático.

\section{Referenciar este material como:}

CASTRO, A. G.; LIMA, M. C.; AQUINO, R. R.; EICKMANN, S. H. Sensory oral motor and global motor development of preterm

5 infants (original title: Desenvolvimento do sistema sensório motor oral e motor global em lactentes pré-termo). Pró-Fono Revista de Atualização Científica, Barueri (SP), v. 19, n. 1, p. 29-38, jan.-abr. 2007. 


\section{Introduction}

The advances in perinatal and neonatal care have led to increased survival among newborns with everlower gestational age and birth weight. However, these babies require careful follow-up, since they present greater vulnerability with regard to abnormalities of neuropsychomotor development (Aurélio et al., 2002; Mancini et al., 2002).

It is observed that, at birth, premature infants have abilities that correspond to their state of maturity. Their exposure to neonatal intensive care and an interactional history that is greatly brought forward require competencies that do not exist yet, thus overloading their process of full development. Therefore, professionals who follow up the evolution of these babies must be alert towards detecting abnormalities and undertaking early intervention. Assessment of overall motor development and oral sensorimotor development is an important part of this follow-up (Méio et al., 2004; Rugolo, 2005).

The theory of dynamics systems proposes that movement and changes in their patterns are generated by various systems in which the components interact and become organized. Within this context, many authors have emphasized that comprehensive assessment of orofacial motricity not only includes observation of oral motor control and sensory responses but also includes other factors such as body weight, muscle strength, weight support, attention, specific context of the environment and the complexity of the task offered (Piper and Darrah, 1994; Morris and Klein, 2000; Howle, 2002; Monson et al., 2003; Rocha et al., 2005; Rogers and Arvedson, 2005).

Although most preterm newborns do not develop severe neurological abnormalities like cerebral palsy, mental deficiency or epilepsy, so-called minor developmental disorders are very prevalent in this population. Prominent among these are attention deficit, minor overall and oral motor abnormalities, delayed language development and behavioral disorders. It has been shown that minor deficits become more visible with increasing age, especially from the fifth month of life onwards. These signs are often not identified at an early stage, because of the lack of measurements that are sufficiently sensitive for detecting motor and behavioral problems within this age group (Wolf et al., 2002; Fontenele et al., 2004; Rugolo, 2005).

Because of this, the present study had the objectives of evaluating associations between the gestational age of infants born prematurely and their overall motor development and between the gestational age and early signs of abnormalities in oral sensorimotor development, and of investigating the possibility of an association between overall and oral sensorimotor development.

\section{Method}

\section{Ethical approval}

The present study was approved by the Ethics Committee for Research on Human Beings of the "Professor Fernando Figueira" Mother and Child Institute, under protocol number 264. Free and informed consent in writing was obtained from the persons responsible for the infants that were included in the study, and all the subjects involved gave their consent for the study to be carried out and for its results to be published.

\section{Study population and location}

The present research consisted of an exploratory study that was carried out at the outpatient department of the Kangaroo Mother Program of the "Professor Fernando Figueira" Mother and Child Institute (IMIP). The interdisciplinary team of this institute consists of pediatricians, nurses, speech therapists, occupational therapists, physiotherapists and psychologists. These professionals systematically follow up the growth and development of infants who were at risk, from birth to two years of life.

Fifty-five preterm infants were included in the present study. Preterm birth was defined as a gestational age of less than 37 weeks, as assessed by a neonatologist during the first 24 hours of life by means of the Capurro method (Capurro et al., 1978). They were assessed when they were four to five months old (chronological age corrected to a gestational age of 40 weeks), at a routine outpatient consultation between March and August 2004. The exclusion criteria for the study were multiple pregnancy, neurological abnormalities during the neonatal period, genetic syndromes and congenital malformations.

Sociodemographic, feeding and biological characteristics of the children

The infants' mothers or caregivers were questioned regarding socioeconomic and demographic conditions, current feeding practice and signs of abnormality regarding extra-oral and intra-oral tactile sensitivity. Information on birth 
weight, gestational age, morbidity and procedures carried out during hospital stay were obtained through analysis of the medical records.

The breastfeeding definitions used were the ones adopted by the World Health Organization, and thus exclusive breastfeeding was considered to be maternal milk intake without any supplements (water, other liquids or solids) during the whole day. Partial breastfeeding was considered to be when the infant took breast milk with other supplements (water, juice, tea, artificial milk or solids) (WHO, 1992).

Assessment of oral sensorimotor development

This assessment was conducted by two authors (the speech therapists ACG and RRA). To test the research forms and standardize the assessment technique, a pilot study involving 10 infants was carried out.

The oral sensorimotor development was assessed by means of a protocol drawn up by the principal investigator (ACG) that was based on the evolution of normal development among infants from four to five months of age, in accordance with the Bobath neuroevolution concept and the Alexander, Boheme and Cupps assessment (1993). When the observed developmental item was what was expected (normal), it was coded as zero (0), and when it was not what was expected (sign of risk), it was coded as one (1). The sum of the signs of risk resulted in an assessment index for the oral sensorimotor system that could range from 0 to 15 .

The infants were examined in the prone and supine postures on a standard mat and when seated on the examiner's lap. Manipulations were performed, consisting of touching the face and oral cavity (proprioceptive tactile stimulus), sometimes with the examiner's hands and sometimes with a standardized toy made of very flexible rubber.

The protocol was composed of 15 items, subdivided into four groups:

. primitive oral reflexes;

. oral motor structures;

. oral emissions;

. arm activity.

\section{Primitive oral reflexes}

In this group, the infants were monitored for the presence of rooting, suckling, gagging and phasic bite reflexes. At the age studied, the presence of any of these reflexes was considered to be a risk factor.

The rooting reflex was assessed by means of touching the cheeks and perioral region and was considered to be present when the infant turned its head and opened its mouth in the direction of the stimulus.

The suckling reflex was assessed by introducing a gloved finger into the infant's oral cavity, between the tongue and the hard palate, and observing whether grasping occurred and rhythmic suction started.

The gagging reflex was tested by touching the gloved index finger on the anterior medial and posterior regions of the tongue and following towards the uvula, posterior wall of the pharynx and soft palate. The reflex was present when, at the time the mouth was open, the head was pulled back and the infant scowled.

The phasic bite reflex was assessed by stimulating the lateral region of the lower gums, and it was considered present when the infant made sequenced chewing movements without contracting the buccinator muscles on the side of the stimulus, as seen by the contraction of the cheek on this side.

\section{Oral motor structures}

This group was assessed by observing the oral structures (lips, tongue, cheeks, mandible and larynx) in activity and at rest, while the infant was exploring a very flexible rubber toy. Absence of the activities or postures described in the following was considered to be a risk factor at this age:

To assess the lips, the infant's activity on the mat in the prone position was observed. The expected posture was that the infant would support its weight on its forearms, with contraction and stretching of the upper lip and lip closure.

To assess the tongue, the infant's position was not standardized. When the rubber toy was introduced into the infant's oral cavity, the examiners assessed the activity of the tongue in the frontal movement plane, as observed by the presence of contraction of the tongue in the lateral region.

The activity of the cheeks was investigated according to symmetrical contraction of the buccinator muscles, unilateral contraction and symmetrical smile. With the infant on the examiner's lap, a rubber toy was introduced into the oral cavity above the tongue. This maneuver was expected to 
trigger symmetrical contraction of the buccinator muscle. To assess the lateral contraction of this muscle, the toy was positioned laterally in the oral cavity, with an expected response of contraction of the buccinator muscle on the side of the stimulus. The presence of a symmetrical smile was assessed during interaction with the examiner, mother and/or caregiver.

Synergic contraction of the levator and depressor muscles was observed for assessing the activity of the mandible, with the infant on the investigator's lap, while exploring the intra-oral region with the toy. The mandible was expected to be aligned with the maxilla, with sufficient excursion of its condyles to enable opening and closing.

The posture of the larynx was assessed with the infant in the prone position on the mat. For the laryngeal posture to be considered adequate (start of its descent), the investigator observed that when looking at the toy that was on the mat, the infant kept its neck stretched and supported the weight of its upper trunk on its forearms.

The presence of normal laryngeal elevation movement during deglutition was assessed with the infant on the investigator's lap, exploring the rubber toy in the oral cavity, thereby stimulating the production of saliva that was then swallowed.

\section{Oral emissions}

The levels of oral emissions were assessed by means of interaction between the infant and the examiner, with toys, and/or with the infant's mother/caregiver. Absence of guttural sounds (gargles) and vocalization during the assessment was considered to be a risk factor.

\section{Symmetrical activity of the arms}

With the infant seated on the examiner's lap or in the supine position on the mat, it was observed whether the infant had the capacity to bring the toy to its mouth with the arms acting symmetrically. Absence of this activity was considered to be a risk factor.

\section{Assessment of overall motor development}

Overall motor development was assessed by using the Alberta Infant Motor Scale (AIMS), which consists of a test that observes the quality of the movement components, such as the infant's ability to transfer its weight, posture adopted in motor tasks and control over muscles that work against gravity. The scale is composed of 58 items divided into four subscales: 21 items in the prone posture; 9 in the supine posture; 12 in the seated posture and 16 in a standing posture. This scale is applicable from birth to 18 months of age.

The result from the assessment consisted of a dichotomized choice for each item, which had to be assessed as "observed" or "not observed". Each item observed in the infant's motor skill repertoire received a score of one, and each item not observed received a score of zero. The observed items on each of the subscales were summed, thus resulting in four subtotals for the subscales of prone, supine, seated and standing. The total score for the test was given by the sum of the subtotals, and could be converted into a motor performance percentage that was established on the basis of the normative sample for the test (Piper and Darrah, 1994).

\section{Results}

The statistical treatment for the data was done using the statistical package Epi-Info version 6.04 (CDC, Atlanta). The typing of the data was done with double data entry, thus enabling its validation. Since the oral sensorimotor development index presented asymmetric distribution, the median and quartiles were used as central trend and dispersion measurements, respectively. The tests for statistical significance used were the chi-squared test for the categorical variables and the non-parametric Kruskal-Wallis test for continuous variables. The significance level adopted was $\mathrm{p} 0.05$.

Table 1 shows that $75 \%$ of the families were classified as poor, with per capita income of less than half a minimum monthly salary. Around 26\% of the mothers were adolescent, $82 \%$ of them were primiparae, all had been to school and $60 \%$ had reached high school level, with or without completing it.

Among the infants studied, in the neonatal phase $56 \%$ had a gestational age of less than or equal to 34 weeks, with a minimum of 29 weeks. All the newborns (except two) presented birth weight of less than $2000 \mathrm{~g}$, and $37 \%$ of them had birth weight of less than $1500 \mathrm{~g}$ (the highest birth weight was $2690 \mathrm{~g})$. Most of the newborns $(87 \%)$ presented an Apgar score of eight of more at the fifth minute of life. Among the most frequent neonatal morbidities were respiratory adaptation syndrome (59\%), respiratory discomfort syndrome $(19 \%)$ and hyperbilirubinemia (68\%). It was observed that $67 \%$ of the newborns remained in hospital for 30 days or less, and $76 \%$ of them were in the rooming-in of 
the Kangaroo Mother Program for 15 days or less. The maximum duration of gavage diet was 58 days, while $41 \%$ of the newborns required feeding by intubation for between two and three weeks. The transition from gavage diet to oral feeding took an average of nine days and did not exceed 17 days. Translactation was performed for $67 \%$ of the newborns and $78 \%$ of the sample was followed up by a speech therapist during the hospital stay.

At the time of the assessment, 23 infants (42\%) had a chronological age of five months, 25 (45\%) of six months and 7 (13\%) of seven months, which corresponded to 38 infants $(69 \%)$ with a corrected age of four months and 17 (31\%) of five months.

Table 2 shows that $78 \%$ of the infants were not receiving exclusive breastfeeding at the time of the assessment and $44 \%$ were using pacifier. Only $5 \%$ of the infants demonstrated dissatisfaction at the time of feeding, $9 \%$ did not like being caressed on the face, $29 \%$ demonstrated discomfort when their faces were being cleaned and also $67 \%$ rejected stimuli with a rough texture on the face. Among the infants who were not exclusively breastfed, $63 \%$ of the mothers used their hand to introduce food into the oral cavity of their children and for $84 \%$ of the infants the food was offered on a spoon. Among the 43 infants who were being bottle-fed, $16 \%$ rejected it and $70 \%$ of the mothers had increased the hole in the teat to obtain a greater flow of the diet. Of the 36 infants who were being fed using a spoon, mashed fruits and vegetables were more frequently offered, although the mothers said that $25 \%$ of the infants did not like this diet. The time spent on feeding using a spoon did not exceed 30 minutes in $71 \%$ of the cases.

Table 3 presents the signs of risk for oral sensorimotor development. Greater frequency of these signs was found among infants with gestational age of less than or equal to 34 weeks than among those with gestational age of 35-36 weeks. The sum of the risk factors resulted in an assessment index for the oral sensorimotor system. Analysis of this index showed that the infants with gestational age of less than 34 weeks presented a higher median for signs of risk for oral sensorimotor development than did those with gestational age of 35-36 weeks $(\mathrm{p}=0.05)$.

Table 4 describes the results from the assessment of overall motor development obtained using AIMS, in percentages. It was found that the percentage of infants with AIMS score below the 10th percentile was significantly greater among those with lower gestational age than among those with higher gestational age $(\mathrm{p}=0.009)$.

Table 5 shows that, among the infants with total AIMS score below the 25 th percentile, the median for the signs of risk for oral sensorimotor development was significantly greater than among those with AIMS score between the 25th and 100th percentiles $(\mathrm{p}<0.001)$. 
TABLE 1. Characterization of the sample with regard to socioeconomic level, mother's demographic data, morbidities and type of feeding during the neonatal period.

\begin{tabular}{|c|c|c|}
\hline Variables & $\mathbf{N}=\mathbf{5 5}$ & $\%$ \\
\hline \multicolumn{3}{|l|}{ Per capita family income (minimum salaries) * } \\
\hline$\leq 0.25$ & 16 & 31 \\
\hline $0.26-0.50$ & 23 & 44 \\
\hline$>0.50$ & 13 & 25 \\
\hline \multicolumn{3}{|l|}{ Mother's age (years) $* *$} \\
\hline$<20$ & 14 & 26 \\
\hline $20-29$ & 33 & 61 \\
\hline$\geq 30$ & 7 & 13 \\
\hline \multicolumn{3}{|l|}{ Parity ** } \\
\hline 1 & 44 & 82 \\
\hline$\geq 2$ & 10 & 18 \\
\hline \multicolumn{3}{|l|}{ Mother's schooling (incomplete + complete) } \\
\hline Elementary & 20 & 36 \\
\hline High school & 33 & 60 \\
\hline University & 2 & 4 \\
\hline \multicolumn{3}{|l|}{ Gestational age (weeks) } \\
\hline $29-32$ & 15 & 27 \\
\hline $33-34$ & 16 & 29 \\
\hline $35-36$ & 24 & 44 \\
\hline \multicolumn{3}{|l|}{ Birth weight $(\mathrm{g}) * *$} \\
\hline$<1500$ & 20 & 37 \\
\hline$\geq 1500$ & 34 & 63 \\
\hline \multicolumn{3}{|l|}{ Apgar at $5^{\text {th }}$ minute $* * *$} \\
\hline$\leq 7$ & 7 & 13 \\
\hline$\geq 8$ & 46 & 87 \\
\hline \multicolumn{3}{|l|}{ Sex } \\
\hline Female & 26 & 47 \\
\hline Male & 29 & 53 \\
\hline \multicolumn{3}{|l|}{$\mathbf{R A S} * *$} \\
\hline Yes & 32 & 59 \\
\hline \multicolumn{3}{|l|}{ RDS ** } \\
\hline Yes & 10 & 19 \\
\hline \multicolumn{3}{|l|}{ Hyperbilirubinemia *** } \\
\hline Yes & 36 & 68 \\
\hline \multicolumn{3}{|l|}{ Hospital stay (days) } \\
\hline$\leq 15$ & 15 & 27 \\
\hline $16-30$ & 22 & 40 \\
\hline$>30$ & 18 & 33 \\
\hline \multicolumn{3}{|l|}{ Stay in neonatal ICU (days) } \\
\hline$\leq 15$ & 38 & 69 \\
\hline $16-30$ & 10 & 18 \\
\hline$>30$ & 7 & 13 \\
\hline \multicolumn{3}{|l|}{ Stay in Kangaroo Mother accommodation (days) } \\
\hline$\leq 15$ & 42 & 76 \\
\hline$>15$ & 13 & 24 \\
\hline \multicolumn{3}{|l|}{ Duration of gavage (weeks) $\dagger$} \\
\hline$\leq 1$ & 18 & 37 \\
\hline $2-3$ & 20 & 41 \\
\hline$\geq 4$ & 11 & 22 \\
\hline \multicolumn{3}{|c|}{ Length of transition from gavage to oral feeding (weeks) $\dagger$} \\
\hline$\leq 1$ & 22 & 48 \\
\hline$>1$ & 24 & 52 \\
\hline \multicolumn{3}{|l|}{ Translactation performed $\ddagger$} \\
\hline Yes & 33 & 67 \\
\hline \multicolumn{3}{|c|}{ Speech therapy follow-up in the Kangaroo Mother accommodation } \\
\hline Yes & 43 & 78 \\
\hline
\end{tabular}

No information: $* 3$ cases; $* * 1$ case; $* * * 2$ cases; $\dagger 6$ cases; $\ddagger 9$ cases

Legend: ICU - intensive care unit; RAS - respiratory adaptation syndrome; RDS - respiratory discomfort syndrome 
TABLE 2. Frequency distribution for current feeding practices and signs of abnormalities in extra-oral and intra-oral tactile sensitivity.

\begin{tabular}{|c|c|c|}
\hline Variables & $\mathbf{N}$ & $\%$ \\
\hline Breastfeeding & $\mathrm{N}=\mathbf{5 5}$ & \\
\hline Exclusive & 12 & 22 \\
\hline Breastfeeding + supplement & 21 & 38 \\
\hline No breastfeeding offered & 22 & 40 \\
\hline \multicolumn{3}{|l|}{ Likes to eat } \\
\hline No & 3 & 5 \\
\hline \multicolumn{3}{|l|}{ Use of pacifier } \\
\hline Yes & 24 & 44 \\
\hline \multicolumn{3}{|l|}{ Likes caresses and kisses on face } \\
\hline No & 5 & 9 \\
\hline \multicolumn{3}{|l|}{ Likes having face cleaned } \\
\hline No & 16 & 29 \\
\hline \multicolumn{3}{|l|}{ Likes rough texture on face } \\
\hline No & 37 & 67 \\
\hline \multicolumn{3}{|l|}{ Use of hand for feeding } \\
\hline Yes & 27 & 63 \\
\hline \multicolumn{3}{|l|}{ Use of spoon for feeding } \\
\hline Yes & 36 & 84 \\
\hline \multicolumn{3}{|l|}{ Likes feeding from bottle } \\
\hline No & 07 & 16 \\
\hline \multicolumn{3}{|l|}{ Hole in bottle teat was increased } \\
\hline Yes & 30 & 70 \\
\hline Among the infants fed from a spoon & $\mathbf{N}=36$ & \\
\hline \multicolumn{3}{|l|}{ Likes feeding from the spoon } \\
\hline No & 9 & 25 \\
\hline \multicolumn{3}{|l|}{ Semi-solid foods offered on a spoon $*$} \\
\hline Mashed fruits & 19 & 54 \\
\hline Mashed vegetables & 8 & 23 \\
\hline Baby food with milk & 6 & 17 \\
\hline All types & 2 & 6 \\
\hline \multicolumn{3}{|l|}{ Time spent feeding from spoon $*$} \\
\hline$\leq 30 \mathrm{~min}$ & 25 & 71 \\
\hline$>30 \mathrm{~min}$ & 10 & 29 \\
\hline
\end{tabular}

* 1 case without information 
TABLE 3. Frequencies of signs of risk and medians for the assessment index for oral sensorimotor development, according to gestational age.

\begin{tabular}{|c|c|c|c|c|c|}
\hline \multirow[t]{2}{*}{ Signs of risk for oral sensorimotor development } & \multicolumn{2}{|c|}{$\begin{array}{c}29-34 \text { weeks } \\
(N=31)\end{array}$} & \multicolumn{3}{|c|}{$\begin{array}{c}35 \text { - } 36 \text { weeks } \\
(N=24)\end{array}$} \\
\hline & $\mathbf{N}$ & $\%$ & $\mathbf{N}$ & & $\%$ \\
\hline \multicolumn{6}{|l|}{ Primitive oral reflexes } \\
\hline Presence of rooting & 13 & 42 & 6 & & 25 \\
\hline Presence of suckling & 14 & 45 & 6 & & 25 \\
\hline Presence of gagging & 1 & 3 & - & & - \\
\hline Presence of phasic bite & 3 & 10 & 2 & & 8 \\
\hline \multicolumn{6}{|l|}{$\begin{array}{l}\text { Oral motor structures } \\
\text { Lins }\end{array}$} \\
\hline Absence of lip contact & 8 & 26 & 2 & & 8 \\
\hline \multicolumn{6}{|l|}{ Tongue } \\
\hline Absence of frontal plane movements & 12 & 39 & 5 & & 21 \\
\hline \multicolumn{6}{|l|}{ Cheeks } \\
\hline Absence of symmetrical contraction of buccinator muscles & 12 & 39 & 5 & & 21 \\
\hline Absence of unilateral contraction of buccinator muscle & 1 & 3 & 4 & & 17 \\
\hline Absence of symmetrical smile & 3 & 10 & 1 & & 4 \\
\hline \multicolumn{6}{|l|}{ Mandible } \\
\hline Absence of alignment & 1 & 3 & - & & - \\
\hline \multicolumn{6}{|l|}{ Larynx } \\
\hline Elevated posture & 15 & 48 & 7 & & 29 \\
\hline Absence of elevation during deglutition & 15 & 48 & 7 & & 29 \\
\hline \multicolumn{6}{|l|}{ Levels of oral emissions } \\
\hline Absence of vocalization & 6 & 19 & 2 & & 8 \\
\hline Absence of guttural sounds / gargles & 11 & 35 & 7 & & 29 \\
\hline \multicolumn{6}{|l|}{ Symmetrical activity of arms } \\
\hline Absent & 10 & 32 & 4 & & 17 \\
\hline \multirow[t]{2}{*}{ Index of signs of risk for oral sensorimotor development } & \multicolumn{3}{|c|}{ Gestational age } & & $\mathbf{p}$ \\
\hline & $29-3$ & reeks & 35 - 36 weeks & & \\
\hline Median (25\% - 75\% quartile) & 5.0 & $(1-7)$ & 0.5 & $(0-5)$ & $0.05 *$ \\
\hline
\end{tabular}

* Kruskal-Wallis test 
TABLE 4. Assessment of overall motor development using AIMS, according to the infants' gestational age.

\begin{tabular}{|c|c|c|c|c|c|}
\hline \multirow{3}{*}{$\begin{array}{l}\text { AIMS score } \\
\text { (percentile) }\end{array}$} & \multicolumn{4}{|c|}{ Gestational age } & \multirow[t]{3}{*}{$\mathbf{p}$} \\
\hline & \multicolumn{2}{|c|}{29 - 34 weeks } & \multicolumn{2}{|c|}{35 - 36 weeks } & \\
\hline & $\mathbf{N}$ & $\%$ & $\mathbf{N}$ & $\%$ & \\
\hline$<10$ & 8 & 26 & 1 & 4 & \\
\hline $10-24$ & 12 & 39 & 5 & 21 & 0.009 \\
\hline $25-100$ & 11 & 35 & 18 & 75 & \\
\hline
\end{tabular}

TABLE 5. Median for signs of risk for oral sensorimotor development according to overall motor development (AIMS).

\begin{tabular}{|c|c|c|c|c|}
\hline \multirow{2}{*}{$\begin{array}{l}\text { AIMS score } \\
\text { (percentile) }\end{array}$} & \multicolumn{3}{|c|}{ Index of signs of risk for oral sensorimotor development } & \multirow[t]{2}{*}{$\mathbf{p}$} \\
\hline & $\mathbf{N}$ & Median & Quartiles (25-75) & \\
\hline$<25$ & 26 & 7 & $(1-10)$ & \multirow{2}{*}{$<0.001 *$} \\
\hline $25-100$ & 29 & 1 & $(0-3)$ & \\
\hline
\end{tabular}

* Kruskal-Wallis test

\section{Discussion}

In this study, it was sought to assess oral sensorimotor development and overall motor development in a sample of infants with a history of prematurity, at a corrected chronological age of four to five months.

Although the sample had few known risk factors for early weaning, since these infants were recruited at a Baby Friendly Hospital Initiative and their mothers were mostly adults and had a reasonable level of schooling, it was found that a considerable number of infants were not receiving exclusive breastfeeding at the time of the assessment. This is contrary to the recommendation from the Ministry of Health and the Pan-American Health Organization (PAHO), which is that supplementary foods should be offered from the sixth month of life onwards. The habits of suckling on pacifiers, using bottle feeding and increasing the flow by opening up the teat were also frequently found in this population. As stated by Neiva et al. (2003), Araújo (2004) and Vitolo (2003), these habits may have contributed towards early weaning and possible alterations to the evolution of the oral sensorimotor system.
In this population, it was seen in relation to supplementary food that most of the infants accepted sweet foods of pasty consistency (mashed fruits) that were offered on a spoon or introduced into the infant's oral cavity on the mother's or a caregiver's hand. The time spent on feeding most of the subjects studied did not exceed 30 minutes. These findings show that the infants presented good evolution regarding the grading of the food consistency, which differs from the results from the studies by Hawdon et al. (2000), Selley et al. (2001) and Monte and Giugliani (2004), who found that their families had difficulty in introducing supplementary food. However, the populations studied by these authors consisted of preterm infants of very low gestational age who presented pneumopathy and required prolonged assisted mechanical ventilation. In our sample, there was lower frequency and severity of perinatal complication, which explains the difference in the results.

We also assessed signs of abnormalities relating to extra-oral and intra-oral tactile sensitivity and found greater prevalence of complaints when 
the tactile stimuli were deeper. Although it was not possible to find any association between this and the gestational age at birth and length of hospital stay, we can infer that such behavior often occurred because of injuries that occurred at the time of hospitalization and the family's lack of capacity for promoting tactile and proprioceptive development (Quresh et al., 2002; Als et al., 2004; Méio et al., 2004).

The results found in the present study show that the children born at younger gestational ages ( $<34$ weeks) presented greater numbers of signs of risk in the assessment index for the oral sensorimotor system. These findings corroborate the data in the literature, which suggest that there is a significant association between the presence of signs of risk for oral sensorimotor development and the gestational age at birth (Bly, 1994; Morris and Klein, 2000; Hoekstra et al., 2004).

Also in this study, it was found that $26 \%$ of the infants presented AIMS percentage score below the 10th percentile. The most premature babies presented the lowest scores, thus indicating retardation of overall motor development in relation to weight support skills, postures adopted for motor tasks and control over muscles working against gravity, at the corrected chronological age of four to five months. Our results are concordant with those of several authors, some of whom using AIMS (Bartlett and Fanning, 2003) or other assessment techniques (Gaetan and Ribeiro, 2002; Fallang et al., 2003). These authors observed that preterm and full-term babies presented similar postural control development up to the third month of life and then started to present differences in their functional repertoires.

Lekskulchai and Cole (2001) used a motor development stimulation program on infants during their first three months of life. They observed that the preterm newborns required systematized multidisciplinary follow-up so that, at the corrected chronological age of four months, they did not present significant differences in motor performance, in comparison with the same age group that had not been exposed to the risks involved in prematurity. These authors suggested that intervention programs might be effective in teaching the mothers how to interact with and adequately stimulate their children, thereby compensating for the biological risk of prematurity.

In the present study, the children who presented AIMS scores below the 25 th percentile had significantly higher medians for the risk factors for oral sensorimotor development. This suggests that there is an association between oral and overall motor development, although the study design did not allow a causal relationship to be established between them.

The beginning of modifications to infants' oral cavities, such as the descent of the larynx (hyolaryngeal complex), is probably associated with growth of the pharynx and the cervical column and should be observed from the fourth month of life (Hiiemae et al., 2002; Rogers and Arvedson, 2005).

Alexander et al. (1993) and also Bly (1994) concluded that the muscles of the tongue and mandible (suprahyoid muscles) required a support base for functional development. The cervical spine and the scapular belt (junction with the infrahyoid muscles) are the basis for this muscle control. Howle (2002) agreed with this association, thus reinforcing the guidelines of the Bobath neuroevolution concept, which states that the adaptive responses needed for an individual's development are the result from interactions between various systems, among which the overall motor and oral sensorimotor systems.

It was seen in the present study that most of the infants did not have extremely low gestational ages and were not affected by severe morbidity. They were followed up by a speech therapist and satisfactory performance was observed in relation to the introduction of food orally at the age group assessed.

The humanized care of the Kangaroo Mother Program that was provided for the infants in our sample may also have contributed towards better self-regulation among the infants during the neonatal period. It also favored a better motherchild relationship, which probably reinforced the practice of stimulating the infants within their family environments (Als et al. 2004; Andrade and Guedes, 2005).

\section{Conclusion}

In this study, larger numbers of abnormal signs were found in assessing the development of the oral sensorimotor system of infants with lower gestational age at birth, in comparison with the group with greater gestational age. The abnormalities most frequently found were the presence of primitive oral reflexes (rooting, suckling and phasic bite), absence of lip contact, absence of tongue activity in the frontal plane, absence of symmetrical activity of the buccinator muscles, larynx in the primitive elevated posture, absence 
of laryngeal elevation during deglutition, absence of symmetrical arm activity in the medial line, and also absence of gargling.

It was also observed that the most premature babies had lower scores in the AIMS assessment, thus indicating risks for overall motor development with regard to weight support skills, postures adopted in motor tasks and control over muscles working against gravity.

Although it was not possible to establish a causal relationship between overall motor and oral sensorimotor parameters, it can be inferred that the difficulties presented by the infants regarding weight support skills, postures established in motor tasks and control over muscles working against gravity made it impossible to achieve developmental gains in the oral sensorimotor system, because of the lack of stretching, symmetry and synergy of the muscles that make up the trunk, scapular belt and neck region.

These findings show the need for follow-up by a speech therapy, using an approach based on the interaction of the overall motor and oral sensorimotor parameters, since these interact and contribute towards the development of motor processing for language. These results further reinforce the need for more dynamic therapeutic management that gives value to actions of multidisciplinary and transdisciplinary nature, in which the various professionals involved will seek the best evidence for appropriate follow-up and stimulation for infants with signs of risk for neuropsychomotor development and oral sensorimotor development.

\section{Acknowledgements}

To the participating families, to the staff of the "Professor Fernando Figueira" Mother and Child Institute (IMIP) and to CNPq for the Research Productivity Grant for Professor Marilia Lima.

\section{References}

ALEXANDER, R.; BOEHME, R.; CUPPS, B. Normal development of functional motor skills. San Antonio: Therapy Skill Builders, 1993.

ALS, H.; LAWHON, G.; DUFFY, F. H.; MCANULTY, G. B.; RIVKIN, M. J.; VAJAPEYAM, S.; MULKERN, R. V.; WARFIELD, S. K.; HUPPI, P. S.; BUTLER, S. C.; CONNEMAN, N.; FISCHER, C.; EICHENWALD, E. C. Early experience alters brain function and structure. Pediatr., Illinois, v. 113, n. 4, p. 846-857, apr. 2004.

ANDRADE, I. S. N.; GUEDES, Z. C. F. Sucção do recémnascido prematuro: comparação do método Mãe-Canguru com os cuidados tradicionais. R. Bras. Saúde Matern. Infant., Recife, v. 5, n. 1, p. 61-69, jan.-mar. 2005.

ARAÚJO, C. M. Alimentação complementar e desenvolvimento sensório motor oral. 2005. $55 \mathrm{f}$. Dissertação (Mestrado de Nutrição em Saúde Pública) Departamento de Nutrição, Universidade Federal de Pernambuco, Recife.

AURÉlio, S. R.; GENARO, K. F.; MACEDO E. D. F. Análise comparativa dos padrões de deglutição de crianças com paralisia cerebral e crianças normais. R. Bras. Otorrinolaringol., São Paulo, v. 68, n. 2, p. 167-173, mar.-abr. 2002.
BARTLETT, D. J.; FANNING, J. E. Use of the Alberta Infant Motor Scale to characterize the motor development of infants born preterm at eight months corrected age. Phys. Occup. Ther. Pediatr., New York, v. 23, n. 4, p. 3145, jan.-mar. 2003.

BLY, L. Motor skills acquisition in the first year. San Antonio: Therapy Skill Builders, 1994.

CAPURRO, H.; KONICHEZKI, D.; FONSECA, D.; CALDEYRO-BARCIA, R. A simplified method for diagnosis of gestational age in the newborn infant. $J$. Pediatr., St. Louis, v. 93, n. 1, p. 120-122, jul. 1978.

FALLANG, B.; SAUGSTAD, O. D.; HADDERS-ALGRA, M. Postural adjustment in preterm infants at 4 and 6 months post-term during voluntary reaching in supine position. Pediatr. Res., Baltimore, v. 54, n. 6, p. 826833, dec. 2003.

FONTENELE, C. C.; SILVINO, F. F.; TERRA, L. C. T.; ALENCAR, M. A.; PINTO, S. M.; FERREIRA, S. M. P. Intervenção precoce. In: LIMA, C. L. A.; FONSECA, L. F. Paralisia Cerebral. Rio de Janeiro: Guanabara Koogan, 2004. cap. 35, p. 321-333.

GAETAN, E. M.; RIBEIRO, M. V. L. M. Developmental study of early posture control in preterm and fullterm infants. Arq. Neuropsiquiatr., São Paulo, v. 60, n. 4, p. 954-958, dec. 2002. 
HAWDON, J. M.; BEAUREGARD, N.; SLATTERY, J.; KENNEDY, G. Identification of neonates at risk of developing feeding problems in infancy. Dev. Med. Child. Neurol., Cambrigde, v. 42, n. 4, p. 235-239, apr. 2000.

HIIEMAE, K. M.; PALMER, J. B.; MEDICIS, S. W.; HEGENER, J.; JACKSON, B. S.; LIEBERMAN, D. E. Hyoid and tongue surface movements in speaking and eating. Arch. Oral Biol., Oxford, v. 47, n. 1, p. 11-27, jan. 2002 .

HOEKSTRA, R. E.; FERRARA, T. B.; COUSER, R. J.; PAYNE, N. R.; CONNETT, J. E. Survival and long-term neurodevelopmental outcome of extremely premature infants born at 23-26 weeks' gestational age at a tertiary center. Pediatr, Illinois, v. 113, n. 1, p. 1-6, jan. 2004.

HOWLE, J. M. Neurodevelopmental treatment approach: theoretical foundations and principles of clinical practice. Canadá: NDTA Treatment Association, 2002.

LEKSKUSCHAI, R.; COLE, J. Effect of a developmental program on motor performance in infants born preterm. Aust. J. Physiother., Victoria, v. 47, n. 3, p. 169-176, jul.sep. 2001

MANCINI, M. C.; CARVAlHO, D. J.; GONTIJO, D. T. Os efeitos da correção da idade no desempenho motor grosso e fino de crianças pré-termo aos dois anos de idade. T. Desenv., São Paulo, v. 11, n. 64, p. 12-19, jan. 2002.

MÉIO, M. D. B. B.; LOPES, C. S.; MORSCH, D. S.; MONTEIRO, A. P. G.; ROCHA, S. B.; BORGES, R. A.; REIS, A. B. Desenvolvimento cognitivo de crianças prematuras de muito baixo peso na idade pré-escolar. $J$. Pediatr., Rio de Janeiro, v. 80, n. 6, p. 495-502, nov.-dez. 2004.

MONSON, R. M.; DEITZ, J.; KARTIN, D. The relationship between awake positioning and motor performance among infants who slept supine. Pediatr. Phys. Ther., Baltimore, v. 15, n. 4, p. 196-203, oct.-dec. 2003.

MONTE, C. M. G.; GIUGLIANI, E. R. J. Recomendações para alimentação complementar da criança em aleitamento materno. J. Pediatr., Rio de janeiro, v. 80, n. 5, p. 131-141, set.-out. 2004.
MORRIS, S. E.; KLEIN, M. D. Pre-feeding skills: a comprehensive resource for mealtime development. San Antonio: Therapy Skill Builders, 2000.

NEIVA, F. C. B.; CATTONI, D. M.; RAMOS, J. L. A.; ISSLER, H. Desmame precoce: implicações para o desenvolvimento motor oral. J. Pediatr., Rio de janeiro, v. 79, n. 1, p. 7-12, jan.-fev. 2003.

PIPER, M. C.; DARRAH, J. Motor assessment of the developing infant. Philadelphia: W.B. Saunders Company, 1994.

QURESHI, M. A.; VICE, F. L.; TACIAK, V. L.; BOSMA, J. F.; GEWOLB, I. H. Changes in rhythmic suckle feeding patterns in term infants in the first month of life. Dev. Med. Child. Neurol., Cambrigde, v. 44, n. 1, p. 34-39, jan. 2002.

ROCHA, N. A. C. F.; TUDELA, E.; BARELA, J. A. Perspectiva dos sistemas dinâmicos aplicados ao desenvolvimento motor. T. Desenv., São Paulo, v. 14, n. 79, p. 5-13, mar.-abr. 2005.

ROGERS, B.; ARVEDSON, J. Assessment of infant oral sensorimotor and swallowing function. Ment. Retard. Dev. Disabil. Res. R., New York, v. 11, n. 1, p. 74-82, jan. 2005.

RUGOLO, L. M. S. S. Crescimento e desenvolvimento a longo prazo do prematuro extremo. J. Pediatr., Rio de janeiro, v. 81, n. 1, p. 101-110, mar. 2005.

SELLEY, W. G.; PARROT, L. C.; LETHBRIDGE, P. C.; FLACK, F. C.; ELLIS, R. E.; JOHNSTON, K. J; FOUMENY, M. A.; TRIPP, J. H. Objective measures of dysphagia complexity in children related to suckle feeding histories, gestational ages, and classification of their cerebral palsy. Dyspha., New York, v. 16, n. 3, p. 200207, may 2001.

VITOLO, M. R. Nutrição: da gestação à adolescência. Rio de Janeiro: Reichmann \& Affonso, 2003.

WOLF, M. J.; KOLDEWIJN, K.; BEELEN, A.; SMIT, B.; HEDLUND, R. Neurobehavioral and developmental ile of very low birthweight preterm infants in early infancy. Acta Paediatr., Oslo, v. 91, n. 8, p. 930-938, aug. 2002. WORLD HEALTH ORGANIZATION. Indicators for assessing breastfeeding practices. Geneva: WHO, 1992. 